\title{
Trend and relationship between environmental accounting disclosure and environmental performance for mining companies listed in China
}

\author{
Andrew Osei Agyemang ${ }^{1}$ (D) Kong Yusheng $^{1} \cdot$ Angelina Kissiwaa Twum $^{1}$. \\ Emmanuel Caesar Ayamba ${ }^{1} \cdot$ Maxwell Kongkuah $^{1} \cdot$ Mohammed Musah $^{1}$
}

Received: 6 July 2020 / Accepted: 15 December 2020 / Published online: 4 January 2021

(c) The Author(s), under exclusive licence to Springer Nature B.V. part of Springer Nature 2021

\begin{abstract}
We examined the effect of environmental disclosure on environmental performance for listed mining companies in China. Our analysis used China's Environmental Information Disclosure Degree (EIDD) and the Chinese Securities Regulatory Commission's disclosure guidelines to propose the Environmental Information Disclosure Index. Majority of previous studies on environmental disclosures focused on a particular company or city or province. Few studies considered a whole sector of a country. Among the few studies that considered a whole industry, none of such studies considered the mining industry. In addition, our study employed a recent environmental disclosure index and modified a recent index for environmental performance for the empirical analysis making our study unique. We also employed vigorous reliability and robustness test to ensure that our findings are valid and can be used by policy-makers. Using panel data for thirty-four mining companies from both Shanghai and Shenzhen Stock Exchange for the period 2000-2018, our cointegration estimation analysis concluded that corporate environmental performance and environmental information disclosure has a positive and significant relationship at a $1 \%$ level. Trend analysis revealed that mining companies comply with environmental information disclosure in China. This was seen from the great improvement in the environmental disclosure for mining companies between 2008 and 2010 after the enforcement of EIDD. Our results contribute to the previous literature and open the way for further studies on industry level in other countries.
\end{abstract}

Keywords China $\cdot$ Environmental disclosure $\cdot$ Environmental performance $\cdot$ Mining

\section{Introduction}

Since the implementation of economic reform and opening-up policy in China, China has sacrificed nature while pursuing the economy's fast-growth. Although the economy has proliferated, the degree of damage to the ecological environment is also severe (Ebenstein

Andrew Osei Agyemang

5102160202@stmail.ujs.edu.cn

Extended author information available on the last page of the article 
et al. 2015). The economic activities of enterprises have created substantial economic profits and social value. However, these achievements have also generated some degree of harm to the natural environment.

Just like international agencies and countries, China attaches great importance to resource conservation and building an environment-friendly society. The concept of green development in China appeared for the first time in the 12th Five-Year Plan and was formulated as the goal of China's long-term sustainable development (Mol et al. 2011). As a tool for enterprises to provide information to information users, accounting has the responsibility of providing corporate environmental information. Using existing financial reports to supplement corporate environmental information disclosure is currently the most common way of environmental accounting information disclosure ( $\mathrm{Lu}$ and $\mathrm{Li}$ 2020; Pien 2020; Tzouvanas et al. 2020). It increases how supplementary information is disclosed in the company's annual report (Iatridis 2013), listing announcement (Tang et al. 2020), prospectus (Pan et al. 2020), and information disclosure in interim reports (Goron 2018).

As China continues to lead the world with production (Wijsman et al. 2019; Taplin and Winterton 2019), production's side effect remains a significant problem (Chen et al. 2019; Sarkodie and Strezov 2019). In 2003, China issued the first environmental information guidelines (Mol et al. 2011). Three years later, the central government issued a public participation impact assessment on environmental disclosure (Hu and Karbhari 2015). In May 2008, enterprises were required to proactively disclose their environmental information (Zeng et al. 2010). Disclosure of environmental accounting information enables users to understand the environmental impact of corporate behavior.

Traditional accounting ignores the scarcity of natural environmental resources (Mather and Chapman 2018). But with the severe depletion of natural resources, environmental problems are becoming more prominent (Fondevila et al. 2019; Odoemelam and Okafor 2018), and traditional accounting can no longer meet the needs of information users. The extreme waste of natural environmental resources and the consequences of pollution has resulted in much attention to environmental protection (Acar and Temiz 2020; Odoemelam and Okafor 2018). Mining companies are facing unprecedented pressure due to innovative accounting methods of environmental cost (Jaskoski 2014; Martinico-Perez et al. 2018). As environmental problems continue to be a major concern of the globe (Lu and Li 2020; Tang et al. 2020; Chen et al. 2019), enterprises are facing pressure from the outside world in terms of minimizing production, which in turn will reduce pollution especially in heavily polluting industries such as mining. Environmental issues severely restrict the development of enterprises. Investors mostly pay attention to the company's financial situation, while little or less attention is paid on its corporate environmental performance (Deswanto and Siregar 2018; Newig et al. 2018). This has led to the need for the mining companies to strengthen environmental accounting so as to achieve coordinated development of economic and environmental benefits.

X. Meng et al. (2014a) compared corporate environmental information disclosure content ratings with environmental performance ratings. Through comparative analysis, it was found that changes in environmental performance would not affect the disclosure of environmental information. Later, Hassan and Romilly (2018) used Canadian companies as samples and found that companies' public decisions are positively correlated with pollution tendency. That is, corporate environmental information disclosure is negatively correlated with environmental performance. Tadros and Magnan (2019) found a significant and positive relationship between environmental performance and quality environmental disclosure. The mixed findings from the relationship between environmental information disclosure and environmental performance have resulted in a literature gap in this study area. 
Taking into account the health impacts of environmental pollution, it is essential for companies that, through their activities, pollute the environment to take some actions to protect the environment. This study, therefore, seeks to (1) examine the compliance of environmental accounting reporting for listed mining companies and (2) explore the relationship that exists between environmental accounting information disclosure and environmental performance for mining companies listed in China.

The study adopted a quantitative research approach. Panel data extracted from a secondary source from the period 2000-2018 for listed mining companies of the two stock exchanges in China mainland were used for the empirical studies. Using Stata version 15 statistical package, Common Correlated Effects Mean Group (CCEMG) and Augmented Mean Group (AMG) estimators were used for the long-run relationship analysis. Our cointegration estimation analysis concluded that corporate environmental performance and environmental information disclosure has a positive and significant relationship at a $1 \%$ level. Trend analysis revealed that mining companies comply with environmental information disclosure in China.

Most of the previous studies on environmental accounting information disclosure focused on a particular company or city or province (Murdifin et al. 2019; Leung and Snell 2019). Few of the studies were able to take a whole industry of a country into consideration (Yao and Liang 2019; Tkachenko et al. 2019). Among the few studies, none of the studies considered the mining industry. Therefore, this study tries to fill the literature gap by taking the mining industry in China as the sample size. This makes the research unique and new. Hence, the findings will add up to the existing literature and open way for other industry studies. The study also used a recent content analysis index for environmental accounting information disclosure (Agyemang et al. 2020). Our study also modified existing environmental performance index (H. Li and Qi 2008). The modification of the model makes our study unique and original.

The study is divided into five sections. The second section reviewed literature related to environmental accounting disclosure and environmental performance. The methodology is presented in the third section of the study. In Sect. 4, the findings and results are discussed in detail. The fourth section also explained the discussion from the results. The final section presented the conclusion and recommendation as well as limitations and future studies for the study.

\section{Literature review}

\subsection{Definition of concepts}

\subsubsection{Environmental accounting information}

Environmental accounting, which is sometimes referred to as 'green accounting' (Cho and Patten 2013; Marissa Matsler 2019) or 'environmental management accounting (Qian et al. 2018; Asiri et al. 2020) is an integral part of the accounting frontier since it combines the traditional accounting reporting with ecological reporting ( $\mathrm{Lu}$ and $\mathrm{Li} 2020$; Tzouvanas et al. 2020). The high rate of pollution has resulted in more studies in this field (G. Li et al. 2018; Kostka and Zhang 2018; Sun et al. 2019). Green accounting mainly uses currency or other non-monetary units to record information related to natural resources and the environment (Cho and Patten 2013). According to Asiri et al. (2020), environmental 
management accounting records the interaction between corporate activities and environmental issues. In the study of Pearce et al. (2013b), environmental accounting's main task is to show the amount of environmental resource wealth, such as the storage of environmental resources, the quantity, and market price. Therefore, environmental accounting information is the provision of information related to both traditional and environmental related issues to stakeholders of accounting information (Vogt et al. 2017; Mather and Chapman 2018; Deswanto and Siregar 2018).

\subsubsection{Environmental performance}

Hahn (2013) defines environmental performance as "the measurable results of an organization's management of its environmental aspects." According to Pien (2020), the minimizing of environmental impact from economic activities measures the environmental performance of a firm.

\subsection{Determinants of environmental information disclosure}

Factors that determine environmental information disclosure can be categorized into internal and external factors (Macagnan and Fontana 2013; Giannarakis et al. 2019; Welbeck et al. 2017). On external factors, the media (Odoemelam and Okafor 2018), government (Welbeck et al. 2017), and consumer (X. Liu and Anbumozhi 2009) all contribute to the disclosure of environmental accounting information. The government can impose laws and fines on companies, thereby compelling companies to disclose the impact of their activities on the environment to information users. External factors, such as regulative pressure (Qian et al. 2018), competitive mechanism (Giannarakis et al. 2019), and pressure from non-government organizations (Welbeck et al. 2017), influence companies' disclosure of environmental information. According to Malafronte et al. (2016), the effects of environmental management's organizational ability from an enterprise's concrete characteristics such as the institutional structure and learning capacity influenced the disclosure of environmental reporting. X. Liu and Anbumozhi (2009) identified external factors such as the media and government as the external determinants of environmental accounting information. In the French context, Y. Wang et al. (2019) suggest that leverage and profitability are determinants of a firm's environmental disclosure.

In terms of internal factors, the company's size is seen to have an effect on the disclosure of environmental information (Passetti et al. 2018; Brooks and Oikonomou 2018). Equally, the debt to equity ratio (Kılıç and Kuzey 2018) and the profitability of the company (Brooks and Oikonomou 2018) influence the company in disclosing environmental accounting information to the stakeholders. Board characteristics cannot be underscored when it comes to internal factors that influence environmental accounting information disclosure (Osazuwa et al. 2016; Passetti et al. 2018). Board characteristics that are identified as determinants of environmental information disclosure in the mining companies are the size of the board (Vogt et al. 2017; Osazuwa et al. 2016; García-Sánchez and MartínezFerrero 2018), the proportion of independent directors (García-Sánchez and Martínez-Ferrero 2018; Cucari et al. 2018), establishment of professional committees (Osazuwa et al. 2016), the female representation of the board (Elmagrhi et al. 2019) CEO duality (Cucari et al. 2018), and age range of board members (Fernandes et al. 2019). 


\subsection{Theoretical literature}

\subsubsection{Environmental economic theory}

Environmental economic theory emphasizes the economy as a subsystem of the ecosystem with its focus upon preserving natural capital (Mol and Sonnenfeld 2014). Environmental economics is an interdisciplinary study of economics and environmental science (Turner et al. 2000). As the industrialization process continues to accelerate, the environment is threatened and destroyed as never before. This has led to an increase awareness of environmental protection. The idea of environmental economics theory helps companies to find a balance between corporate development and environmental protection. That is, to minimize the environmental impact of economic activities and also ensure sustainable development (Fondevila et al. 2019; Taplin and Winterton 2019).

\subsubsection{Theory of sustainable development}

Sustainable development means meeting the present's needs without prejudice to the ability of future generations to meet their own needs (Giangrande et al. 2019). That is, the protection of natural resources and the development of environmental sustainability (Ghai and Vivian 2014). This idea can be traced back to the Silent Spring, published in 1962 (Sikdar 2003). Sustainable development is a scientific and economic growth model that requires development to be closely related to the environment (Giangrande et al. 2019; Elmagrhi et al. 2019). To ensure the synchronization of environmental development and economic development, China has put forward a sustainable development strategy, emphasizing that it can be adopted in the environment to create material wealth within the scope of the acceptance (Pearce et al. 2013a).

\subsection{Environmental accounting disclosure and compliance}

Based on the theory of environmental economics, which states that, as economic activities continue, the environment is affected in one way or another. Hence, companies must put adequate measures in protecting the environment from destruction so that future generations can also benefit from natural resources, as indicated by the theory of sustainable development. Qian and Chen (2020) believes that the overall assessment of environmental accounting information disclosure refers to the degree of the information disclosed, satisfying all stakeholders' demand.

Environmental compliance measures how companies conform to environmental laws (McGuire 2014), regulations (Zeng et al. 2010), standards (Goron 2018), and other requirements such as site permits to operate. Due to the recent environmental concerns, there has been a need to measure companies' activities to verify if companies comply with environmental regulations. Prior studies on environmental compliance have a mixed conclusion. In the study of Sun et al. (2019), the study realized that less than half of the sample companies complied with environmental reporting. On the contrary, Odoemelam and Okafor (2018) concluded that more than seventy percent $(70 \%)$ of the sample companies complied with the environmental disclosures. The above literature eventually leads to the first hypothesis, which states that: 
H1 Listed mining companies comply with environmental accounting information.

\subsubsection{Environmental performance and environmental disclosures}

Researchers began to pay attention to the relationship between environmental performance and environmental accounting information disclosure in the past two decades (Tang et al. 2020; Y. Wang et al. 2019; Welbeck et al. 2017). The conclusions of the relationship between the two are not conclusive. Some researchers found an inverse or insignificant relationship between environmental performance and environmental accounting information (Clarkson et al. 2008; Belhaj and Damak-Ayadi 2011; Al-Tuwaijri et al. 2004; Acar and Temiz 2020). Mathuva and Kiweu (2016) compared content analysis ratings of environmental disclosures that appeared in corporate annual reports to environmental performance ratings. The study did not find a significant association between environmental disclosure and environmental performance. Using a GMM method to evaluate environmental disclosures in annual reports, Seles et al. (2019) found an insignificant relationship between environmental disclosure and Indian listed companies' environmental performance.

X. H. Meng et al. (2014a) based on China's 97 heavily polluting listed companies' empirical analysis of short-panel data from 2011 to 2015 and found that environmental performance is positively correlated with environmental information disclosure. Z. Liu (2020) found that energy efficiency and technology innovation resulted in a significant increase in environmental performance levels and improved environmental disclosure index level. Using voluntary disclosure theory, Tadros and Magnan (2019) empirical study found a positive and statistically significant relationship between environmental accounting information disclosure and environmental performance for oil and gas companies in the USA. Zhang and Xie (2020) through the establishment of an environmental information disclosure index evaluation system, employed a comprehensive analysis of the relationship between environmental information disclosure and environmental performance of listed companies in the light-polluting industry using GMM estimation technique. The authors found that the quality of industrial environmental performance and environmental information changes are in the same direction, that is, the better the environmental performance, the higher the quality of environmental disclosure. Esty and Karpilow (2019) compiled the Federal Government Toxic Substances Inventory (TRI) using environmental information disclosure indicators to test the effectiveness of information disclosure in realizing the actual improvement of corporate environmental performance effectiveness. The authors of the study found that over time, environmental information disclosure has a positive and statistically significant impact on the environmental performance. Basing on the above positive relationship between environmental information and disclosure, this study also assumes that:

H2 There exists a positive correlation between environmental performance and environmental accounting information disclosure for Chinese listed mining companies.

\section{Methodology}

\subsection{Research design}

The study used secondary data extracted from annual reports, financial statements, and environmental reports from the Environmental Protection Agency of the sample 
companies. The research covered 19 financial years from January 1, 2000, to December 31, 2018. This period was selected because of the availability of data. Due to the global pandemic of new coronavirus, data for the year 2019 were not released on time. Hence, 2019 was excluded from the study. Critical consideration was also used in selecting the variables. Most researchers in economics and accounting use Stata statistical tool for empirical analysis (Longest 2019; Fondevila et al. 2019; Deswanto and Siregar 2018). Our study also utilized Stata version 15 for the empirical analysis since this kind of statistical software performs a series of statistical analysis on the sample data, and explores the statistical values and related relations of the variables in the model (Longest 2019).

\subsection{Population and sampling}

In considering the study population, the authors considered the country that leads the world in terms of carbon emissions for the year 2019. China was then selected since it contributed to 30\% of carbon emissions for 2019 (Chen et al. 2019), thereby toping the world in terms of carbon emissions (Tadros and Magnan 2019). This was due to the enormous export market as a result of high manufacturing companies situated in China ( $\mathrm{Lu}$ and $\mathrm{Li}$ 2020; Taplin and Winterton 2019). Since pollution is a side effect of manufacturing, countries leading in manufacturing contribute significantly to pollution (Moutinho et al. 2020; Haibo et al. 2019; Ayamba et al. 2020).

In order to select the sample size, the authors explored the various sectors and industries to ascertain the level of direct air pollution. In effect, the mining industry was the number one major contributor of direct air pollution. Hence, the mining industry in China was selected for the study. The mining industry is defined as including exploration for, and extraction and primary processing of, minerals, including processing up to the first pouring of the refined metals (Fan et al. 2017). In China, the mining industry is divided into five main subsectors, namely mining of coal, petroleum and natural gas extraction, ferrous metal mining, nonferrous metal mining and non-metal ores mining.

In order to get reliable data, the study considered only listed mining companies. As at December 31, 2019, there were 45 and 21 listed mining companies on the Shanghai Stock Exchange and Shenzhen Stock Exchange respectively. However, due to missing data for some companies for some years, the final sample had 22 and 12 mining companies from the Shanghai and Shenzhen stock exchanges.

\subsection{Model specification}

In testing the relationship between environmental performance and environmental accounting information disclosure, the study adopts and modify (Patten 2002) econometric model, which is given in (Eq. 1)

$$
\mathrm{EADI}_{\mathrm{it}}=\beta_{0}+\beta_{1} \mathrm{EPI}_{\mathrm{it}}+\beta_{2} \mathrm{SIZE}_{\mathrm{it}}+\beta_{3} \mathrm{LEV}_{\mathrm{it}}+\beta_{4} \mathrm{ROE}_{\mathrm{it}}+\varepsilon
$$

where EADI represents Environmental Accounting Disclosure Index, EPI represents Environmental Performance Index, SIZE denotes size of the company measured by total assets, LEV representing the degree of debt measured by total liabilities, and ROE, which denotes return on equity of the mining companies. In the model, $\beta 0$ represents the constant, $\varepsilon$ denotes the error term, $i$ is the sample company, and $t$ is the year. 


\subsection{Variables}

\subsubsection{Environmental accounting disclosure index (EADI)}

In the empirical research on information disclosure, content analysis is the most widely used and most important analytical method (Manes-Rossi et al. 2018; Osei et al. 2019; Tang et al. 2018; Leopizzi et al. 2020). Our study also used the content analysis method to evaluate the level of corporate environmental accounting information disclosure. In estimating EADI, our study adopted an index proposed by Agyemang et al. (2020) where scores are recorded and summed. This index was used because it is the most recent developed index for measuring environmental information disclosure in China's mining industry. Considering the unique nature of the environmental information disclosure degree, the EADI proposed by (Agyemang et al. 2020) measurement are based on the rules and regulations of the accounting standards and disclosure guidelines formulated by the China Securities Regulatory Commission, the environmental information disclosure measures, environmental information disclosure degree, and the characteristics of China's mining industry. The environmental disclosure index proposed by (Agyemang et al. 2020) is categorized into two themes, namely environmental financial information and environmental non-financial information. According to the adopted index, three points was scored for detailed description or disclosure. One point was scored for fairly disclosure, while for no disclosure, 0 point was scored. EADI is obtained by dividing the score of the sample company by the total score of 54 . The calculation formula is given as:

$$
\mathrm{EADIi}=\Sigma \mathrm{EADIi} / \Sigma \mathrm{MEADIi}
$$

, where $\sum$ EADIi and $\sum$ MEADIi represent environmental accounting information of the sample company and the highest score of all disclosures, respectively.

\subsubsection{Environmental performance index}

Environmental performance is a construct that has received significant attention from researchers in the past three decades (Hsu and Zomer 2014; Ağan et al. 2016; Singh et al. 2020; Index 2018). However, its complexity and multidimensional character have prevented researchers and regulators from reaching a consensus on how to measure this variable. In measuring corporate environmental performance, some research used the database of Toxic Release Inventory (TRI) (Esty and Karpilow 2019; Index 2018), and the database of the Council on Economic Priorities (CEP) (Haibo et al. 2019; Newig et al. 2018). These two databases provided data for developed countries only. The unavailability of data still restrains studies on Chinese corporate environmental performance. L. Wang et al. (2018) established a framework to comprehensively evaluate Chinese firms' corporate environmental performance, based on the following criteria:

1. The firm was not involved in "The Report on Punishment for Environmental Pollution."

2. The firm adopted ISO 14,001 or other relevant environmental management systems.

3. The firm was awarded the honor of "National Environmentally Friendly Enterprise" by the Municipal Environmental Protection (MEP) at provincial levels.

4. The firm was awarded the honor of "National Environmentally Friendly Enterprise" by the Municipal Environmental Protection (MEP) at national levels. 
This study modified the way previous studies evaluated the environmental performance index and proposed a new way of measuring corporate environmental performance index for Chinese companies. The research estimates corporate environmental performance as Yes and No.

Scores were then assigned to the four (4) items and aggregated as a ratio to the total score - three (3) points for the Yes indicator and Zero (0) point for No indicator. Corporate environmental performance is then obtained by dividing the sample company's score by a total score of 12 . The higher the score, the higher the environmental performance of the company. The calculation formula is given as

$$
\mathrm{EPIi}=\Sigma \text { EPIi } / \Sigma \text { TEPIi, }
$$

where $\sum$ EPIi and $\sum$ TEPIi represent the environmental performance and the highest score of environmental performance, respectively.

\subsubsection{Control variables}

3.4.3.1 Company size Company size has featured as an essential variable or determinant of disclosure levels (Iatridis 2013). In general, there are three leading indicators for measuring the size of a company: market value (D'Amico et al. 2016), operating income (Giannarakis et al. 2019), and total assets (Welbeck et al. 2017). The market value is greatly affected by market fluctuations and has more significant uncertainty (X. Liu and Anbumozhi 2009). Operating income is affected by external influences (Z. Liu 2020). Hence, total assets are mostly used to measure the size of the company (Giannarakis et al. 2019; Welbeck et al. 2017; Fonseka et al. 2019). Therefore, this study uses the logarithm of total assets at the end of the year to measure the size of the company.

3.4.3.2 Leverage D'Amico et al. (2016) believe that the company's voluntary information is positively related to leverage. Fonseka et al. (2019) also found that environmental information disclosure is positively affected by the level of corporate debt. Macagnan and Fontana (2013) conducted an empirical study of relevant data from large UK companies and found enterprises with low debt levels have high environmental information disclosure. Total debt is used to measure the leverage of the company.

3.4.3.3 Profitability The Return on Equity (ROE) measures the company's net income in contrast to each unit of shareholder equity (Tripathi et al. 2018). By comparing the company's net income to its overall wealth, the ROE indicates whether the net income is appropriate for its size.

\subsection{Data processing and presentation}

The data were divided into three panels for the analysis. Panel $A$ was made up of only state-owned mining companies listed on both the Shanghai and Shenzhen Stock Exchange. Panel $B$ comprised only privately owned mining companies listed in China, and Panel $C$ was a combination of both state-owned and private companies in China. The data were made up of twenty-two state-owned companies and twelve private mining companies.

We first performed descriptive statistics to determine the nature of the data set. The Pearson correlation matrix was then performed to know how the pair of variables are 
related. To enable the authors to select appropriate estimation techniques, we then carried a cross-sectional dependency test and unit root test. The findings from these tests influenced our selection of CCEMG and AMG cointegration estimators for the regression analysis. To determine the causalities among the study variables, the pairwise Granger causality was performed. Finally, trend analysis was carried out to help in ascertaining the trend of compliance of environmental accounting information disclosure and environmental performance for listed mining companies in China.

\section{Findings and analysis}

\subsection{Descriptive statistics and correlation analysis}

Table 1 shows that the average EADI score is $0.6024,0.5894$, and 0.5993 for state-owned companies, privately owned companies, and a combination of state-owned and privateowned companies, respectively, with a minimum score of $0.3200,0.3900$, and 0.3200 for Panel $A, B$, and $C$, respectively. The findings revealed that the EADI is above average for all three panels, indicating that most mining companies disclose adequate environmental information to their stakeholders.

In terms of the independent variable, the standard deviation and mean of EPI for Panel $C$ are 0.1063 and 0.5904 , respectively, indicating that environmental performance is also above average and that majority of the sample companies have high (above average) environmental performance. Similarly, taking state-owned and private companies individually, the EPI is still above average. However, the average EPI for state-owned was slightly higher than that of the private companies.

The VIF analysis findings revealed relatively small values for all three panels indicating that multicollinearity does not exist among the study variables. The Pearson correlation analysis findings further affirm that multicollinearity does not exist since all the coefficients from the correlation matrix were below 0.8 .

The dependent and explanatory variables in the three panels recorded a negative skewed value. However, the values were not more than -0.5 . This indicated that they are relatively symmetrical. All three panels recorded a kurtosis value of less than 3 for the dependent and the explanatory variables, indicating fewer and less extreme outliers than the normal distribution.

From the Pearson correlation analysis results in Table 2, there was a mixture of medium and weak correlations among the study variables. All the variables except ROE recorded a medium correlation with the predicted variable for the three panels. The findings show that the environmental performance index (EPI), the company size (SIZE), and debt ratio measured by leverage are statistically significantly positively correlated with the listed mining company's environmental information disclosure level (EADI) at the level of $1 \%$ for all the three panels, while ROE was found to be negatively correlated with EADI for all the three panels.

\subsection{Cross-sectional dependency analysis}

The cross-sectional dependence test in Table 3 shows that all the variables for Panel $A$ (state-owned companies) and Panel $C$ (state-owned and private companies combined) recorded a $1 \%$ significant level. Similarly, all variables in Panel B (private companies) 


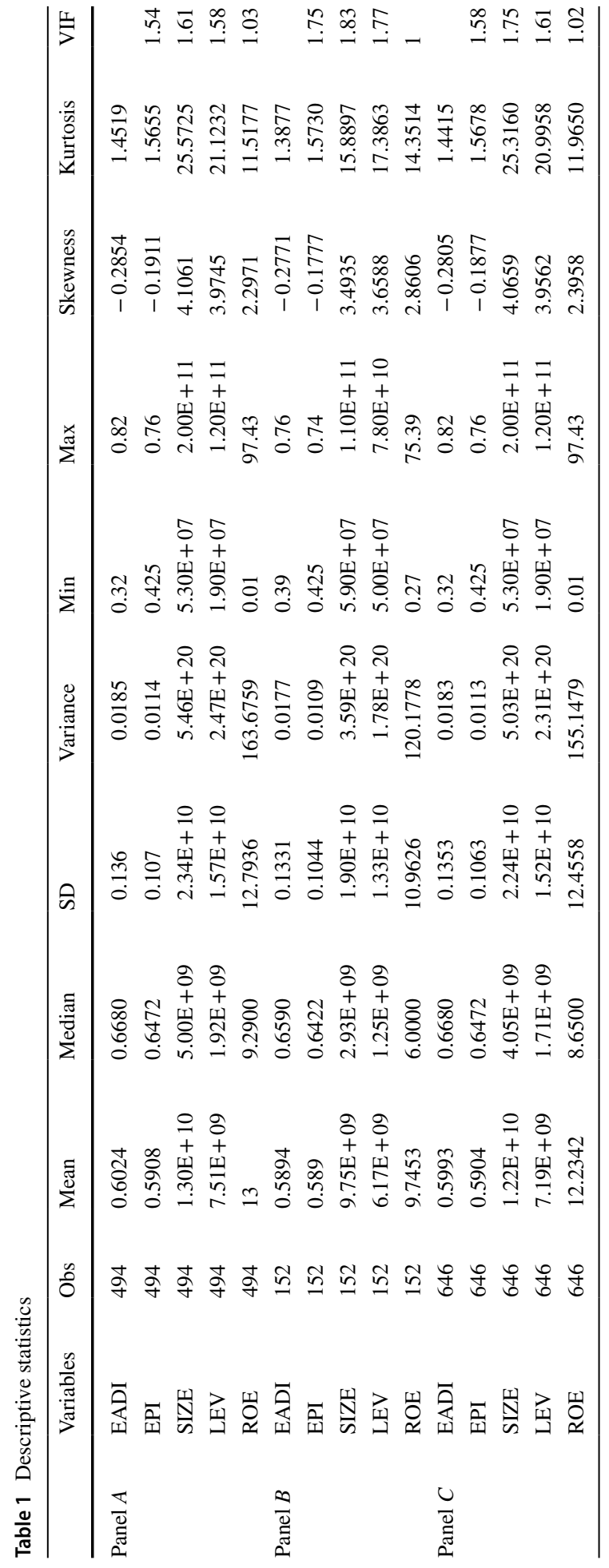


Table 2 Pearson correlation analysis

\begin{tabular}{|c|c|c|c|c|c|c|}
\hline & Variables & EADI & EPI & SIZE & LEV & ROE \\
\hline \multirow[t]{5}{*}{ Panel $A$} & EADI & 1.0000 & & & & \\
\hline & EPI & $0.5533 * * *$ & 1.0000 & & & \\
\hline & SIZE & $0.5893 * * *$ & $0.5791 * * *$ & 1.0000 & & \\
\hline & LEV & $0.5558 * * *$ & $0.5475 * * *$ & $0.5556^{* * *} *$ & 1.0000 & \\
\hline & ROE & $-0.109 * *$ & $-0.1431 * * *$ & -0.0206 & 0.0038 & 1.0000 \\
\hline \multirow[t]{5}{*}{ Panel $B$} & EADI & 1.0000 & & & & \\
\hline & EPI & $0.6580 * * *$ & 1.0000 & & & \\
\hline & SIZE & $0.6359 * * *$ & $0.6537 * * *$ & 1.0000 & & \\
\hline & LEV & $0.6003 * * *$ & $0.6185^{* * *}$ & $0.6354 * * *$ & 1.0000 & \\
\hline & ROE & $-0.0569 * *$ & -0.0583 & -0.0208 & -0.0144 & 1.0000 \\
\hline \multirow[t]{5}{*}{ Panel $C$} & EADI & 1.0000 & & & & \\
\hline & EPI & $0.6538 * * *$ & 1.0000 & & & \\
\hline & SIZE & $0.6004 * * *$ & $0.5932 * * *$ & 1.0000 & & \\
\hline & LEV & $0.5664 * * *$ & $0.5624 * * *$ & $0.6497 * * *$ & 1.0000 & \\
\hline & ROE & $-0.0934 * *$ & $-0.1241 * * *$ & -0.0097 & 0.0054 & 1.0000 \\
\hline
\end{tabular}

**** $1 \%$ significant level, **5\% significant level, *10\% significant level

Table 3 Cross-sectional dependency test

\begin{tabular}{|c|c|c|c|c|c|}
\hline & Variables & Breusch-Pagan LM & Pesaran scaled LM & $\begin{array}{l}\text { Bias-corrected } \\
\text { scaled LM }\end{array}$ & Pesaran CD \\
\hline \multirow[t]{5}{*}{ Panel $A$} & EADI & $6043.10 * * *$ & $224.28 * * *$ & $223.56 * * *$ & $77.74 * * *$ \\
\hline & EPI & $6121.93 * * *$ & $227.37 * * *$ & $226.65 * * *$ & $78.24 * * *$ \\
\hline & SIZE & $3657.91 * * *$ & $130.73 * * *$ & $130.01 * * *$ & $56.90 * * *$ \\
\hline & LEV & $2936.50 * * *$ & $102.43 * * *$ & $101.71 * * *$ & $39.02 * * *$ \\
\hline & ROE & $684.90 * * *$ & $14.12 * * *$ & $13.39 * * *$ & $8.02 * * *$ \\
\hline \multirow[t]{5}{*}{ Panel $B$} & EADI & $527.76 * * *$ & $66.78 * * *$ & $66.56 * * *$ & $22.97 * * *$ \\
\hline & EPI & $528.65 * * *$ & $66.90 * * *$ & $66.68 * * *$ & $22.99 * * *$ \\
\hline & SIZE & $320.09 * * *$ & $39.03 * * *$ & $38.81 * * *$ & $17.64 * * *$ \\
\hline & LEV & $235.47 * * *$ & $27.72 * * *$ & $27.50 * * *$ & $14.73 * * *$ \\
\hline & ROE & $48.84 * * *$ & 2.78 & $2.56^{*}$ & 1.24 \\
\hline \multirow[t]{5}{*}{ Panel $C$} & EADI & $10,466.00 * * *$ & $295.70 * * *$ & $294.76 * * *$ & $102.30 * * *$ \\
\hline & EPI & $10,573.55^{* * *}$ & $298.92 * * *$ & $297.97 * * *$ & $102.83 * * *$ \\
\hline & SIZE & $6377.46^{* * *}$ & $173.64 * * *$ & $172.70 * * *$ & $75.96 * * *$ \\
\hline & LEV & $5058.83 * * *$ & $134.28 * * *$ & $133.33 * * *$ & $55.15^{* * *}$ \\
\hline & ROE & $1016.75 * * *$ & $13.61 * * *$ & $12.66 * * *$ & $7.88 * * *$ \\
\hline
\end{tabular}

$* * *, * *, *$ denote $1 \%, 5 \%$ and $10 \%$ significant level respectively

except for ROE also recorded a $1 \%$ significant level. In Panel $B$, ROE recorded insignificant cross-section dependence for both Pesaran scaled LM and Pesaran CD test. Since most of the variables recorded significant relationships among the study variables, we conclude the existence of cross-sectional dependency among the study variables. This implies that 
by virtue of the study variables' social characteristics, the variables are interrelated and not dependent on individual mining companies. Hence, we accept Ho and reject Ha. This indicates that the $\mathrm{n}$ variables in the sample are no longer independently drawn observations but affect each other's outcomes.

\subsection{Unit root}

From Table 4, the CIPS unit root test results show that SIZE and LEV for the three panels are not stationary at level I (0) since they recorded values which were lower than the critical value of -1.47 for constant, and -2.58 for constant and trend. After differencing at first level, the null hypothesis (Ho) is rejected, indicating that the study variables are integrated at order one, I (1) because all the values were above the critical values.

\subsection{Cointegration estimation}

The study used the Common Correlated Effects Mean Group estimator (CCEMG) in Model 1. In the CCEMG estimator, the unobservable common factor is treated as a nuisance. That is, something to be accounted for that is not of particular interest in the empirical analysis (Cucari et al. 2018). In Model 2, the Augmented Mean Group estimator (AMG), which was developed in (Eberhardt 2011) was used to analyze the robustness of results. Table 5 provides the results of the cointegration estimation analysis.

Table 5 shows that the Probability $>$ chi2 value and the $F$ statistic for Model 1 and Model 2 of the three panels are less than 0.01 , implying a $1 \%$ statistically significant cointegration model. Therefore, the cointegration estimation model is considered excellent, and estimation analysis can be performed for state-owned companies, private companies, and

Table 4 CIPS unit root

\begin{tabular}{|c|c|c|c|c|c|}
\hline \multirow[t]{2}{*}{ Panels } & \multirow[t]{2}{*}{ Variables } & \multicolumn{2}{|l|}{ Level } & \multicolumn{2}{|c|}{ 1st difference } \\
\hline & & Constant & Constant and trend & Constant & Constant and trend \\
\hline \multirow[t]{5}{*}{ Panel $A$} & EADI & -2.863 & -3.159 & -4.639 & -4.684 \\
\hline & EPI & -2.727 & -2.751 & -4.179 & -4.414 \\
\hline & SIZE & -1.308 & -1.857 & -3.494 & -3.654 \\
\hline & LEV & -1.26 & -1.788 & -3.723 & -3.883 \\
\hline & ROE & -3.044 & -3.967 & -5.18 & -5.084 \\
\hline \multirow[t]{5}{*}{ Panel $B$} & EADI & -2.366 & -3.015 & -4.582 & -4.559 \\
\hline & EPI & -2.475 & -2.229 & -3.846 & -4.752 \\
\hline & SIZE & -0.687 & -1.789 & -3.47 & -3.889 \\
\hline & LEV & -0.996 & -1.733 & -3.236 & -3.814 \\
\hline & ROE & -2.435 & -2.577 & -4.582 & -4.662 \\
\hline \multirow[t]{5}{*}{ Panel $C$} & EADI & -2.74 & -3.149 & -4.69 & -4.74 \\
\hline & EPI & -2.673 & -2.636 & -4.095 & -4.442 \\
\hline & SIZE & -1.193 & -1.87 & -3.51 & -3.692 \\
\hline & LEV & -1.335 & -1.795 & -3.772 & -3.939 \\
\hline & ROE & -2.883 & -3.512 & -5.079 & -5.027 \\
\hline
\end{tabular}


Table 5 Cointegration estimation analysis

\begin{tabular}{|c|c|c|c|c|c|c|}
\hline \multirow[t]{2}{*}{ Variables } & \multicolumn{2}{|l|}{ Panel $A$} & \multicolumn{2}{|l|}{ Panel $B$} & \multicolumn{2}{|l|}{ Panel $C$} \\
\hline & Model 1 & Model 2 & Model 1 & Model 2 & Model 1 & Model 2 \\
\hline EPI & $1.2389 * * *$ & $1.2229 * * *$ & $0.7811 * * *$ & $0.9325 * * *$ & $1.1417 * * *$ & $1.1565 * * *$ \\
\hline SIZE & 0.0003 & -0.0022 & 0.0058 & 0.0178 & 0.0118 & 0.0000 \\
\hline LEV & -0.0035 & -0.0008 & -0.0011 & -0.0079 & -0.0055 & -0.0001 \\
\hline ROE & -0.0010 & -0.0006 & -0.0030 & -0.0013 & -0.0015 & -0.0009 \\
\hline EADI & $0.9673 * * *$ & & $1.0066 * * *$ & & $0.9738 * * *$ & \\
\hline EPI & $-1.1800 * * *$ & & $-0.8244 * * *$ & & $-1.0972 * * *$ & \\
\hline SIZE & 0.0049 & & 0.0028 & & 0.0050 & \\
\hline LEV & -0.0081 & & -0.0005 & & -0.0164 & \\
\hline ROE & -0.0002 & & 0.0069 & & 0.0007 & \\
\hline Prob $>$ chi 2 & 0.0001 & 0.0000 & 0.0000 & 0.0000 & 0.0000 & 0.0000 \\
\hline
\end{tabular}

$* * *, * *, *$ denote $1 \%, 5 \%$ and $10 \%$ significant level respectively

the combination of state-owned companies and private companies in Panel $A$, Panel $B$, and Panel $C$, respectively.

Table 5 shows that the EPI and EADI are significantly positively correlated at the level of $1 \%$ for both Model 1 and Model 2. This indicates that a one-unit increase in environmental performance index results in $1.2389,0.7811$, and 1.1417 changes in the environmental information disclosure for state-owned mining companies, private mining companies, and a combination of state-owned and private-owned companies, respectively, in Model 1. Similarly, using cross-section averaged regressors for state-owned in Panel $A$, private-owned in Panel B, and a combination of state-owned and private-owned mining companies in Panel $C$ for Model 1, EADI recorded a significant and positive correlation at $1 \%$ level for Model 1. In contrast, EPI recorded significant and negative correlations. Also, for every unit change in EPI, it resulted in 1.2229, 0.9325, and 1.1565 change in EADI and vice versa for Panel $A, B$, and $C$, respectively, in Model 2. The positive and significant relationship shows that as environmental performance increases, it results in the increase in environmental information disclosure for the listed mining companies.

Using model 1, hypothesis 2 is confirmed. That is, the is a positive relationship between EADI and EPI for listed mining companies in China. The robust model (Model 2) also affirms the hypothesis.

\subsection{Granger causality test}

The pairwise Granger causality test found a bidirectional, no causality, and uni-directional causality among the three panels. Table 6 provides the details of the causality among the variables, which was displayed at a lag of 2 .

The results revealed a mixture of bi-directional causality for EADI and EPI in all three panels. Similarly, bi-directional causality was seen in only state-owned companies (Panel A) for ROE on EPI. This implies that EADI causes EPI and vice versa. That is, an increase in EADI will increase EPI. That is, a long-run correlation was found between the two.

For the three panels, the study revealed that no causality exists between ROE and EADI, SIZE and EPI, LEV and EPI, ROE and SIZE, ROE and LEV. Similarly, ROE and EPI have 
Table 6 Pairwise Granger causality test

\begin{tabular}{|c|c|c|c|}
\hline Null hypothesis: & Panel $A$ & Panel $B$ & Panel $C$ \\
\hline $\mathrm{EPI} \neq \mathrm{EADI}$ & $28.9365 * * *$ & $5.7291 * * *$ & $33.9183 * * *$ \\
\hline $\mathrm{EADI} \neq \mathrm{EPI}$ & $235.6920 * * *$ & $82.3675^{* * *}$ & $317.0450 * * *$ \\
\hline SIZE $\neq=\mathrm{EADI}$ & 0.7463 & 1.4927 & 1.3663 \\
\hline $\mathrm{EADI} \neq \mathrm{SIZE}$ & 1.8644 & 0.6287 & 2.2255 \\
\hline $\mathrm{LEV} \neq \mathrm{EADI}$ & 0.5452 & 0.3397 & 0.8058 \\
\hline $\mathrm{EADI} \neq \mathrm{LEV}$ & 1.5703 & 0.7702 & 1.9704 \\
\hline $\mathrm{ROE} \neq \mathrm{EADI}$ & 1.9611 & 1.4311 & 2.9890 \\
\hline $\mathrm{EADI} \neq \mathrm{ROE}$ & 3.6729 & 1.6652 & 2.0216 \\
\hline SIZE $\neq=\mathrm{EPI}$ & 1.1715 & 1.0291 & 2.0928 \\
\hline $\mathrm{EPI} \neq \mathrm{SIZE}$ & 1.3415 & 1.1387 & 2.3094 \\
\hline $\mathrm{LEV} \neq \mathrm{EPI}$ & 0.674 & 1.7523 & 1.3634 \\
\hline $\mathrm{EPI} \neq \mathrm{LEV}$ & 1.4858 & 1.1792 & 1.4169 \\
\hline $\mathrm{ROE} \neq \mathrm{EPI}$ & $5.9124 * * *$ & 0.6427 & $3.9385 * *$ \\
\hline $\mathrm{EPI} \neq \mathrm{ROE}$ & $3.1148 * *$ & 1.3909 & 1.1808 \\
\hline $\mathrm{LEV} \neq \mathrm{SIZE}$ & 0.3126 & 0.2535 & 0.3517 \\
\hline $\mathrm{SIZE} \neq \mathrm{LEV}$ & $3.2252 * *$ & $16.8408 * * *$ & $14.5151 * * *$ \\
\hline $\mathrm{ROE} \neq \mathrm{SIZE}$ & 0.3705 & 0.2814 & 0.3397 \\
\hline $\mathrm{SIZE} \neq \mathrm{ROE}$ & 1.048 & 0.6667 & 0.4389 \\
\hline $\mathrm{ROE} \neq \mathrm{LEV}$ & 0.2676 & 0.0059 & 0.2780 \\
\hline $\mathrm{LEV} \neq \mathrm{ROE}$ & 0.5733 & 0.3122 & 0.1833 \\
\hline
\end{tabular}

$* * *, * *, *$ denote $1 \%, 5 \%$ and $10 \%$ significant level, respectively $\neq$ denote does not granger cause

shown no causality for private-owned companies in Panel B. That is, the above variables cannot cause the other.

Uni-directional causality was seen in the three panels for SIZE and LEV. Also, ROE and EPI for Panel $C$ revealed a uni-directional causality. This implies that the mining company's size causes leverage, but leverage does not cause the mining company's size. Similarly, profitability measured by ROE can cause EPI, but EPI cannot cause ROE.

\subsection{Trend of environmental disclosure and environmental performance}

\subsubsection{Environmental disclosure trend}

Figures 1 and 2.

\subsubsection{Environmental performance trend}

The study used trend analysis to show environmental disclosure and environmental performance for state-owned mining companies and private mining companies in China. The trend analysis revealed a common slope for both Environmental Disclosure and Environmental Performance for all the sample companies. Per the outcome for the trend analysis, from 2008, there was a swift increase in the environmental information disclosure, which subsequently increased the sample companies' environmental performance. After the swift 

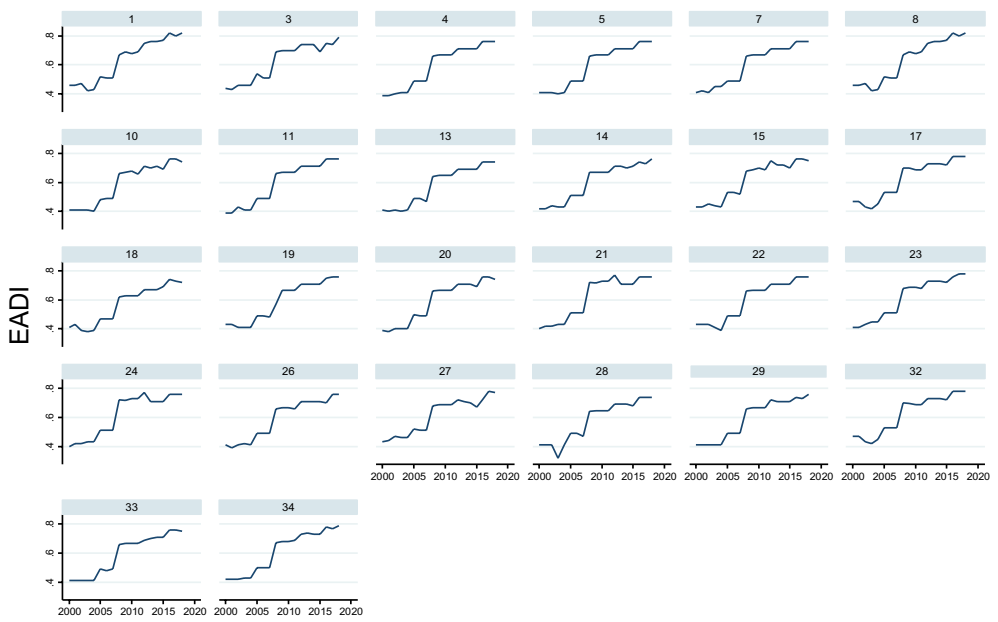

Graphs by ID

\section{Year}

Fig. 1 State-owned companies

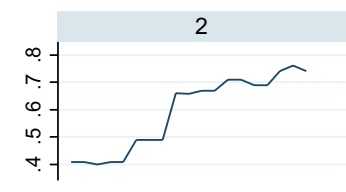

12

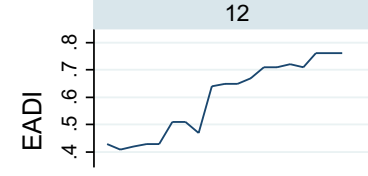

30

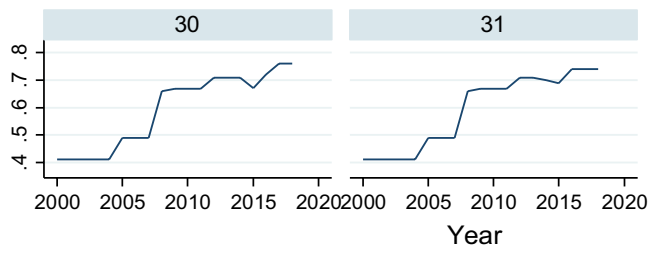

Graphs by ID
6

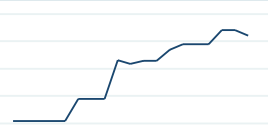

16

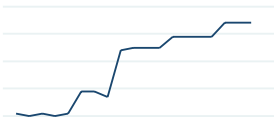

\begin{tabular}{ccccc}
$T^{\prime}$ & \multicolumn{1}{c}{${ }^{\prime}$} & & & \\
2000 & 2005 & 2010 & 2015 & 2020
\end{tabular}

25

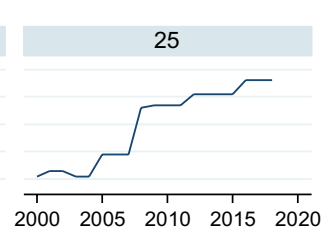

9

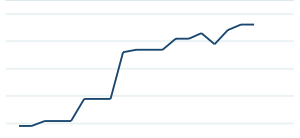

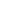

Fig. 2 Private companies

increase in 2008, the increase continued creepily till 2017. There was little change in the environmental information disclosure for 2017 and 2018. Generally, environmental information disclosure saw a massive improvement after the Environmental Information Disclosure Degree (EIDD) in May 2008.

The trend analysis confirms the CCEMG and AMG cointegration estimation results. As environmental information disclosure increases, it results in an increase in environmental performance for all the sample companies. 


\subsection{Discussion}

Due to the national and local governments' environmental information regulations and policies, most of the sample companies comply with the regulations and hence disclose environmental-related information caused by their economic activities. This eventually resulted in a high disclosure score for both environmental disclosure and environmental performance. Contrary, Decker and Pope (2005) revealed that less than half of the sample companies complied to environmental reporting, the findings from the descriptive analysis for the three panes of the study indicates that, more than half of the sample comply to environmental disclosures as stipulated by the EIDD in China.

From the perspective of disclosure quality, companies are more inclined to qualitative and quantitative disclosure. Majority of the companies chose to disclose information related to environmental accounting in their annual reports such as "Financial Statements and Notes", "Report of the Board of Directors" and "Management Discussion and Analysis" Some companies also reported their environmental activities in their Social Responsibility Report similar to the findings of (Pedersen et al. 2013). The mining companies listed in China made a good effort in disclosing their environmental activities to all shareholders.

Basing on environmental economic theory and the theory of sustainable development, our study assumed a positive relationship between environmental accounting information disclosure and environmental performance. The correlation analysis and the cointegration estimation for both models for the three panel confirmed the study's second assumption. That is, EPI and EADI are significantly positively correlated at the level of 1\%, which indicates that a unit increase in EADI, will result in the EPI and vice versa. The cointegration estimation analysis findings are similar to the findings of (Acar and Temiz 2020; Hassan and Romilly 2018; Tadros and Magnan 2019).

Hassan and Romilly (2018) found a significant and positive relationship between environmental performance and quality environmental disclosure. That is, companies with good environmental performance can distinguish themselves from companies with poor environmental performance with sufficient and high-quality environmental information. Similarly, Acar and Temiz (2020) urges companies to pay attention to improve environmental performance in the production and operation process, and actively disclose environmental Information. Based on the above literature, it can be found that from a long-term perspective, enterprises are encouraged to improve environmental information disclosure as well as environmental protection. This will inevitably improve environmental performance. Environmental performance is beneficial to the enterprise, society, and government. Under a sound environmental management system, the market mechanism is fully functional (Tadros and Magnan 2019). In this regard, information disclosure plays an important role in promoting the improvement of corporate environmental performance. Based on the above literature, our study assumed a positive and statistically significant relationship between environmental information disclosure and environmental performance. (Fig. 3).

Due to the lack of effective supervision, the environmental accidents that have been caused have spread to a wide range, and the consequences are serious (Giannarakis et al. 2019; Welbeck et al. 2017). This has raised concerns for environmental compliance. Several countries have paid attention to the importance of environmental information disclosure (Artene et al. 2020; Belhaj and Damak-Ayadi 2011; Chen et al. 2019; Murdifin et al. 2019). After years of exploration and attempts, the information disclosure 

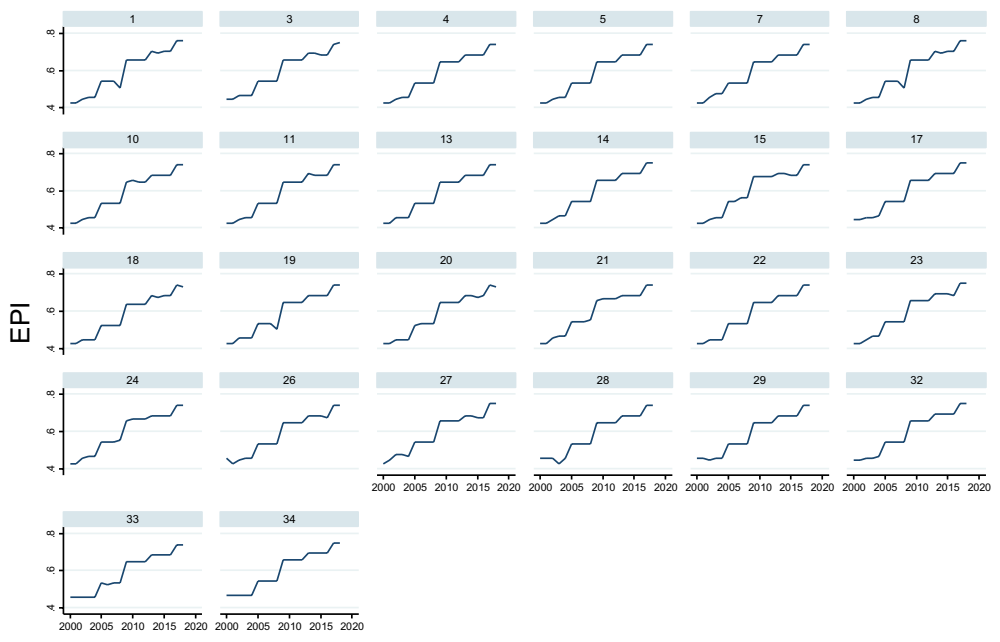

Graphs by ID

Year

Fig. 3 State-owned companies

system has been revised and improved significantly. Considering high rate of production, pollution has been one of the major concerns in China. This eventually led to the implementation of environmental information disclosure degree in May 2008. After the promulgation of the EIDD, measuring compliance has been of great concerns. (Fig. 4).

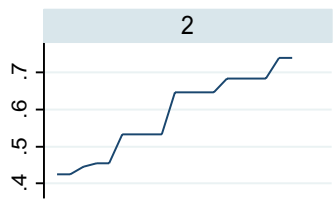

12

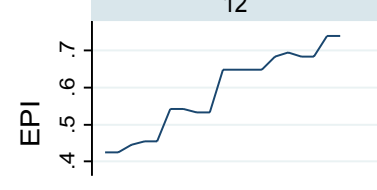

30

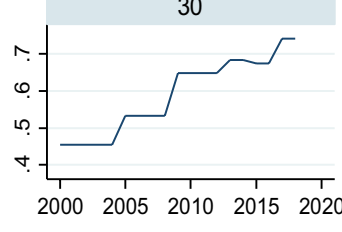

Graphs by ID

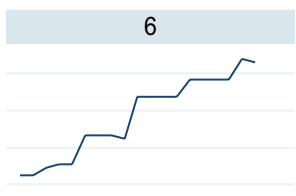

16

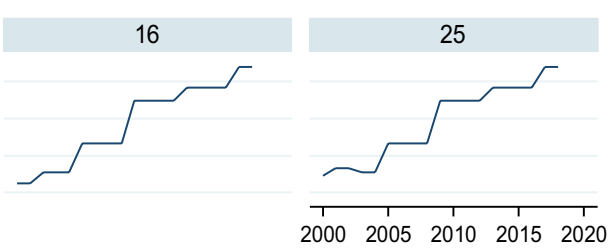

31

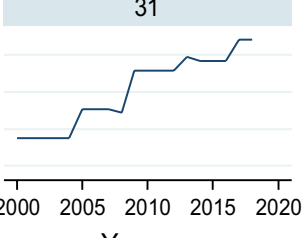

Year

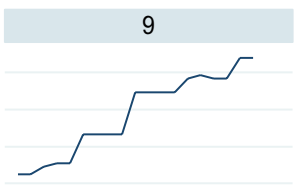

25

Fig. 4 Private companies 
After China's effort on the legislation of information disclosure in 2008, the development of an environmental auditing system, and the start of web-based pollutant emission and transfer register was put in place. This eventually compelled all companies in China to report on their environmental information about economic activities. Hence, there was a significant improvement in the environmental disclosure for mining companies between 2008 and 2010. The increase continued gradually till 2018. Per the way EADI increased from 2008 to 2018, as compared to how EADI was creeping from 2000 to 20,007, it can be seen that the enforcement of the Environmental Information Disclosure Degree worked effectively. The trend analysis affirms hypothesis 1, which says mining companies comply with environmental information disclosure in China. The findings from our study are in line with the findings of Artene et al. 2020; Giannarakis et al. 2019; and Pan et al. 2020. Artene et al. (2020) using a sample of 65 Romanian listed companies from 2011 to 2013 found that the environmental information disclosure trends have seen a major improvement over the past decade. Similarly, Giannarakis et al. (2019) show that companies which have established environmental management systems has made the greatest contribution to its environmental protection awards, and in effect have improved the trends of environmental disclosures. Our findings are consistent with our theoretical foundation. That is, after the environmental information disclosure degree was implemented in May 2008, the trend of environmental information disclosure has improved.

\section{Conclusion and implications}

\subsection{Conclusion}

Using panel data from 2000 to 2018, this study explores the relationship that exists between environmental information disclosure and environmental performance for mining companies listed in China. Also, we analyzed how mining companies comply with environmental information disclosure promulgated by the Environmental Information Disclosure Degree in China. In order to ensure that the findings from the study are reliable and valid, the study employed a more proficient panel estimation method in the analysis. The findings from the study revealed the existence of cross-sectional dependency among the variables. Also, the findings from the CIPS test revealed the variables are integrated at first difference level.

The empirical study's cointegration estimation analysis concluded that corporate environmental performance and environmental information disclosure have a positive and significant relationship at a $1 \%$ level, which is consistent with the original assumptions of this study (hypothesis 2). In addition to the above, return on equity and leverage had a negative and insignificant correlation with environmental disclosure and environmental performance. That is, as the profitability of the mining company and debt funding ratio increases, it reduces environmental disclosure for mining companies.

Using the Pairwise Granger test to analyze the causalities, the study recorded bi-directional, uni-directional and no causality among the variables.

Trend analysis confirmed the first hypothesis that mining companies comply with environmental information disclosure in China. This was seen from the great improvement in the environmental disclosure for mining companies between 2008 and 2010 after the enforcement of EIDD. The increase continued gradually till 2018.

Based on these findings, the study recommends the provision of environmental subsidies which will bring considerable economic and social benefits to enterprises. This will 
encourage companies to pursue green production actively by introduces advanced energysaving and emission-reduction equipment. Also, the reward and punishment system should be enforced. This will ensure compliance with environmental reporting and in the longrun, improve environmental performance. Lastly, sensitizing the public to keep an eye on environmental-related issues will help in reducing environmental destruction and instead, promote environmental performance.

\subsection{Implications}

The findings from our studies affirm the fact that increase in environmental information disclosure reflects in an increase in environmental performance of mining companies. With the growing concern of sustainable development, different countries are implementing different strategies to promote both economic and environmental development. Since China leads the world with global manufacturing, side effect of production such as pollution continues to be of major concerns. This therefore calls for the improvement in environmental information disclosure for companies in China so as to enhance environmental performance and reduce carbon emissions as production still continues. Strict policies such as the usage of environmentally friendly plants should be put in place to reduce carbon emissions. In terms of academic implications, since China leads the world with highest carbon emission, the attention by researchers in conducting empirical and theoretical studies on environmental related issues in China is on the rise now. This study will add to the existing literature.

Funding National Natural Science Foundation of China (No. 71973054).

Code availability Not applicable.

Data availability Available.

\section{Compliance with ethical standards}

Conflicts of interest The author(s) declare that they have no competing interests.

\section{References}

Acar, M., \& Temiz, H. (2020). Empirical analysis on corporate environmental performance and environmental disclosure in an emerging market context. International Journal of Emerging Markets, 15(6), 1061-1082.

Ağan, Y., Kuzey, C., Acar, M. F., \& Açıkgöz, A. (2016). The relationships between corporate social responsibility, environmental supplier development, and firm performance. Journal of cleaner production, 112, 1872-1881.

Agyemang, A. O., Yusheng, K., Ayamba, E. C., Twum, A. K., Chengpeng, Z., \& Shaibu, A. (2020). Impact of board characteristics on environmental disclosures for listed mining companies in China. Environmental Science and Pollution Research, 27, 1-14.

Al-Tuwaijri, S. A., Christensen, T. E., \& Hughes Ii, K. (2004). The relations among environmental disclosure, environmental performance, and economic performance: A simultaneous equations approach. Accounting, Organizations and Society, 29(5-6), 447-471. 
Artene, A., Bunget, O.-C., Dumitrescu, A.-C., Domil, A.-E., \& Bogdan, O. (2020). Non-financial information disclosures and environmental protection-evidence from Romania and Greece. Forests, 11(8), 814.

Asiri, N., Khan, T., \& Kend, M. (2020). Environmental management accounting in the middle east and North Africa region: Significance of resource slack and coercive isomorphism. Journal of cleaner production, 267, 121870. https://doi.org/10.1016/j.jclepro.2020.121870.

Ayamba, E. C., Haibo, C., Abdul-Rahaman, A.-R., Serwaa, O. E., \& Osei-Agyemang, A. (2020). The impact of foreign direct investment on sustainable development in China. Environmental Science and Pollution Research, 20, 1-13.

Belhaj, M., \& Damak-Ayadi, S. (2011). Financial performance, environmental performance and environmental disclosure: the case of Tunisian firms. Afro-Asian Journal of Finance and Accounting, 2(3), $248-269$.

Brooks, C., \& Oikonomou, I. (2018). The effects of environmental, social and governance disclosures and performance on firm value: A review of the literature in accounting and finance. The British Accounting Review, 50(1), 1-15.

Chen, Y., Wang, Z., \& Zhong, Z. (2019). CO2 emissions, economic growth, renewable and non-renewable energy production and foreign trade in China. Renewable Energy, 131, 208-216.

Cho, C. H., \& Patten, D. M. (2013). Green accounting: Reflections from a CSR and environmental disclosure perspective. Critical Perspectives on Accounting, 24(6), 443-447. https://doi.org/10.1016/j. cpa.2013.04.003.

Clarkson, P. M., Li, Y., Richardson, G. D., \& Vasvari, F. P. (2008). Revisiting the relation between environmental performance and environmental disclosure: An empirical analysis. Accounting, Organizations and Society, 33(4-5), 303-327.

Cucari, N., Esposito De Falco, S., \& Orlando, B. (2018). Diversity of board of directors and environmental social governance: Evidence from Italian listed companies. Corporate Social Responsibility and Environmental Management, 25(3), 250-266.

D’Amico, E., Coluccia, D., Fontana, S., \& Solimene, S. (2016). Factors influencing corporate environmental disclosure. Business strategy and the environment, 25(3), 178-192.

Decker, C. S., \& Pope, C. R. (2005). Adherence to environmental law: The strategic complementarities of compliance decisions. The Quarterly Review of Economics and Finance, 45(4), 641-661. https://doi. org/10.1016/j.qref.2004.06.001.

Deswanto, R. B., \& Siregar, S. V. (2018). The associations between environmental disclosures with financial performance, environmental performance, and firm value. Social Responsibility Journal, 14, 180-193.

Ebenstein, A., Fan, M., Greenstone, M., He, G., Yin, P., \& Zhou, M. (2015). Growth, pollution, and life expectancy: China from 1991-2012. American Economic Review, 105(5), 226-231.

Eberhardt, M. Panel time-series modeling: New tools for analyzing xt data. In 2011 UK Stata Users Group meeting, 2011.

Elmagrhi, M. H., Ntim, C. G., Elamer, A. A., \& Zhang, Q. (2019). A study of environmental policies and regulations, governance structures, and environmental performance: The role of female directors. Business strategy and the environment, 28(1), 206-220.

Esty, D. C., \& Karpilow, Q. (2019). Harnessing investor interest in sustainability: The next frontier in environmental information regulation. Yale J. on Reg., 36, 625.

Fan, Y., Bai, B., Qiao, Q., Kang, P., Zhang, Y., \& Guo, J. (2017). Study on eco-efficiency of industrial parks in China based on data envelopment analysis. Journal of environmental management, 192, 107-115.

Fernandes, S. M., Bornia, A. C., \& Nakamura, L. R. (2019). The influence of boards of directors on environmental disclosure. Management Decision, 57(9), 1-26. https://doi.org/10.1108/MD-11-2017-1084.

Fondevila, M. M., Moneva, J. M., \& Scarpellini, S. (2019). Environmental disclosure and Eco-innovation interrelation. The case of Spanish firms. Revista de Contabilidad-Spanish Accounting Review, 22(1), 73-87.

Fonseka, M., Rajapakse, T., \& Richardson, G. (2019). The effect of environmental information disclosure and energy product type on the cost of debt: Evidence from energy firms in China. Pacific-Basin Finance Journal, 54, 159-182.

García-Sánchez, I. M., \& Martínez-Ferrero, J. (2018). How do independent directors behave with respect to sustainability disclosure? Corporate Social Responsibility and Environmental Management, 25(4), 609-627.

Ghai, D., \& Vivian, J. M. (2014). Grassroots environmental action: people's participation in sustainable development (Vol. 4): Routledge.

Giangrande, N., White, R. M., East, M., Jackson, R., Clarke, T., Saloff Coste, M., et al. (2019). A competency framework to assess and activate education for sustainable development: Addressing the UN sustainable development goals 4.7 challenge. Sustainability, 11(10), 2832. 
Giannarakis, G., Andronikidis, A., \& Sariannidis, N. (2019). Determinants of environmental disclosure: Investigating new and conventional corporate governance characteristics. Annals of Operations Research, 294, 1-19.

Goron, C. (2018). Ecological civilisation and the political limits of a Chinese concept of sustainability. China Perspectives, 2018(2018/4), 39-52.

Hahn, R. (2013). ISO 26000 and the standardization of strategic management processes for sustainability and corporate social responsibility. Business strategy and the environment, 22(7), 442-455.

Haibo, C., Ayamba, E. C., Agyemang, A. O., Afriyie, S. O., \& Anaba, A. O. (2019). Economic development and environmental sustainability - the case of foreign direct investment effect on environmental pollution in China. Environmental Science and Pollution Research, 26(7), 7228-7242.

Hassan, O. A., \& Romilly, P. (2018). Relations between corporate economic performance, environmental disclosure and greenhouse gas emissions: New insights. Business strategy and the environment, 27(7), 893-909.

Hsu, A., \& Zomer, A. (2014). Environmental performance index (pp. 1-5). Wiley StatsRef: Statistics Reference Online.

Hu, Y. Y., \& Karbhari, Y. (2015). Incentives and disincentives of corporate environmental disclosure: Evidence from listed companies in China and Malaysia. Thunderbird International Business Review, 57(2), 143-161.

Iatridis, G. E. (2013). Environmental disclosure quality: Evidence on environmental performance, corporate governance and value relevance. Emerging Markets Review, 14, 55-75.

Index, E. P. (2018). Environmental performance index. New Haven, CT, USA: Yale University and Columbia University.

Jaskoski, M. (2014). Environmental licensing and conflict in Peru's mining sector: A path-dependent analysis. World development, 64, 873-883.

Kılıç, M., \& Kuzey, C. (2018). Determinants of forward-looking disclosures in integrated reporting. Managerial Auditing Journal, 33, 115-144.

Kostka, G., \& Zhang, C. (2018). Tightening the grip: Environmental governance under Xi Jinping (Vol. 27, pp. 769-781). Taylor \& Francis.

Leopizzi, R., Iazzi, A., Venturelli, A., \& Principale, S. (2020). Nonfinancial risk disclosure: The "state of the art" of Italian companies. Corporate Social Responsibility and Environmental Management, 27(1), 358-368.

Leung, T.C.-H., \& Snell, R. S. (2019). Strategies for social and environmental disclosure: The case of multinational gambling companies. Journal of business ethics, 492, 1-21.

Li, G., He, Q., Shao, S., \& Cao, J. (2018). Environmental non-governmental organizations and urban environmental governance: Evidence from China. Journal of environmental management, 206, 1296-1307.

Li, H., \& Qi, A. (2008). Impact of corporate governance on voluntary disclosure in Chinese listed companies. Corporate Ownership and control, 5(2), 360-366.

Liu, X., \& Anbumozhi, V. (2009). Determinant factors of corporate environmental information disclosure: An empirical study of Chinese listed companies. Journal of cleaner production, 17(6), 593-600. https ://doi.org/10.1016/j.jclepro.2008.10.001.

Liu, Z. (2020). Unraveling the complex relationship between environmental and financial performance A multilevel longitudinal analysis. International Journal of Production Economics, 219, 328-340. https://doi.org/10.1016/j.ijpe.2019.07.005.

Longest, K. C. (2019). Using Stata for quantitative analysis (Vol. 20): SAGE Publications.

Lu, J., \& Li, H. (2020). The impact of government environmental information disclosure on enterprise location choices: Heterogeneity and threshold effect test. Journal of cleaner production. https://doi. org/10.1016/j.jclepro.2020.124055.

Macagnan, C. B., \& Fontana, F. (2013). Factors explaining the level of voluntary human capital disclosure in the Brazilian capital market. Intangible Capital, 9(1), 305-321. https://doi.org/10.3926/ic.315.

Malafronte, I., Porzio, C., \& Starita, M. G. (2016). The nature and determinants of disclosure practices in the insurance industry: Evidence from European insurers. International Review of Financial Analysis, 45, 367-382. https://doi.org/10.1016/j.irfa.2015.02.003.

Manes-Rossi, F., Tiron-Tudor, A., Nicolò, G., \& Zanellato, G. (2018). Ensuring more sustainable reporting in Europe using non-financial disclosure-De facto and de jure evidence. Sustainability, 10(4), 1162.

Marissa Matsler, A. (2019). Making 'green' fit in a 'grey' accounting system: The institutional knowledge system challenges of valuing urban nature as infrastructural assets. Environmental Science \& Policy, 99, 160-168. https://doi.org/10.1016/j.envsci.2019.05.023.

Martinico-Perez, M. F. G., Schandl, H., Fishman, T., \& Tanikawa, H. (2018). The socio-economic metabolism of an emerging economy: monitoring progress of decoupling of economic growth and environmental pressures in the Philippines. Ecological Economics, 147, 155-166. 
Mather, A. S., \& Chapman, K. (2018). Environmental resources (Vol. 5). London: Routledge.

Mathuva, D. M., \& Kiweu, J. M. (2016). Cooperative social and environmental disclosure and financial performance of savings and credit cooperatives in Kenya. Advances in Accounting, 35, 197-206. https://doi.org/10.1016/j.adiac.2016.09.002.

McGuire, W. (2014). The effect of ISO 14001 on environmental regulatory compliance in China. Ecological Economics, 105, 254-264. https://doi.org/10.1016/j.ecolecon.2014.06.007.

Meng, X., Zeng, S., Shi, J. J., Qi, G., \& Zhang, Z. (2014a). The relationship between corporate environmental performance and environmental disclosure: An empirical study in China. Journal of environmental management, 145, 357-367.

Mol, A. P., He, G., \& Zhang, L. (2011). Information disclosure in environmental risk management: Developments in China. Journal of Current Chinese Affairs, 40(3), 163-192.

Mol, A. P., \& Sonnenfeld, D. A. (2014). Ecological modernisation around the world: Perspectives and critical debates (Vol. 1): Routledge.

Moutinho, V., Madaleno, M., \& Elheddad, M. (2020). Determinants of the environmental Kuznets curve considering economic activity sector diversification in the OPEC countries. Journal of cleaner production, 271, 122642.

Murdifin, I., Pelu, M. F. A., Perdana, A. A. H., Putra, K., Arumbarkah, A. M., Muslim, M., et al. (2019). Environmental disclosure as corporate social responsibility: Evidence from the biggest nickel mining in Indonesia. International journal of Energy Economics and policy, 9(1), 115.

Newig, J., Challies, E., Jager, N. W., Kochskaemper, E., \& Adzersen, A. (2018). The environmental performance of participatory and collaborative governance: A framework of causal mechanisms. Policy Studies Journal, 46(2), 269-297.

Odoemelam, N., \& Okafor, R. G. (2018). The influence of corporate governance on environmental disclosure of listed non-financial firms in Nigeria. Indonesian Journal of Sustainability Accounting and Management, 2(1), 25-49.

Osazuwa, N. P., Che-Ahmad, A., \& Che-Adam, N. (2016). Board characteristics and environmental disclosure in Nigeria. International Information Institute (Tokyo). Information, 19(8), 3069.

Osei, A. A., Yusheng, K., Caesar, E. A., Kissiwaa, A. T., \& Shaibu, A. (2019). Impact of board characteristics on corporate social responsibility disclosure in Ghana. International Journal of Sciences: Basic and Applied Research, 46(1), 104-116.

Pan, Y., Chen, Q., \& Zhang, P. (2020). Does policy uncertainty affect corporate environmental information disclosure: evidence from China. Management and Policy Journal: Sustainability Accounting.

Passetti, E., Cinquini, L., \& Tenucci, A. (2018). Implementing internal environmental management and voluntary environmental disclosure. Accounting, Auditing \& Accountability Journal, 31(4), 1-32. https://doi.org/10.1108/AAAJ-02-2016-2406.

Patten, D. M. (2002). The relation between environmental performance and environmental disclosure: A research note. Accounting, Organizations and Society, 27(8), 763-773.

Pearce, D., Barbier, E., \& Markandya, A. (2013a). Sustainable development: economics and environment in the Third World (Vol. 5). London Environmental Economics Centre: Routledge.

Pearce, D., Markandya, A., \& Barbier, E. (2013b). Blueprint 1: for a green economy (Vol. 4): Routledge.

Pedersen, E. R. G., Neergaard, P., Pedersen, J. T., \& Gwozdz, W. (2013). Conformance and deviance: Company responses to institutional pressures for corporate social responsibility reporting. Business strategy and the environment, 22(6), 357-373.

Pien, C.-P. (2020). Local environmental information disclosure and environmental non-governmental organizations in Chinese prefecture-level cities. Journal of Environmental Management, 275, 111225. https://doi.org/10.1016/j.jenvman.2020.111225.

Qian, W., \& Chen, X. (2020). Corporate environmental disclosure and political connection in regulatory and leadership changes: The case of China. The British Accounting Review, 100935.

Qian, W., Hörisch, J., \& Schaltegger, S. (2018). Environmental management accounting and its effects on carbon management and disclosure quality. Journal of cleaner production, 174, 1608-1619. https://doi.org/10.1016/j.jclepro.2017.11.092.

Sarkodie, S. A., \& Strezov, V. (2019). Effect of foreign direct investments, economic development and energy consumption on greenhouse gas emissions in developing countries. Science of the Total Environment, 646, 862-871.

Seles, B. M. R. P., de Sousa, L., Jabbour, A. B., Jabbour, C. J. C., Latan, H., \& Roubaud, D. (2019). Do environmental practices improve business performance even in an economic crisis? extending the win-win perspective. Ecological Economics, 163, 189-204. https://doi.org/10.1016/j.ecole con.2019.04.013.

Sikdar, S. K. (2003). Sustainable development and sustainability metrics. AIChE journal, 49(8), 1928-1932. 
Singh, S. K., Del Giudice, M., Chierici, R., \& Graziano, D. (2020). Green innovation and environmental performance: The role of green transformational leadership and green human resource management. Technological Forecasting and Social Change, 150, 119762.

Sun, D., Zeng, S., Chen, H., Meng, X., \& Jin, Z. (2019). Monitoring effect of transparency: How does government environmental disclosure facilitate corporate environmentalism? Business strategy and the environment, 28(8), 1594-1607.

Tadros, H., \& Magnan, M. (2019). How does environmental performance map into environmental disclosure? Management and Policy Journal: Sustainability Accounting.

Tang, Y., Miao, X., Zang, H., \& Gao, Y. (2018). Information disclosure on hazards from industrial water pollution incidents: Latent resistance and countermeasures in China. Sustainability, 10(5), 1475.

Tang, Y., Yang, R., Chen, Y., Du, M., Yang, Y., \& Miao, X. (2020). Greenwashing of local government: The human-caused risks in the process of environmental information disclosure in China. Sustainability, 12(16), 6329.

Taplin, I. M., \& Winterton, J. (2019). Rethinking global production (Vol. 26): Routledge.

Tkachenko, I. N., Pervukhina, I. V., \& Sokolovskaya, O. E. (2019), Environmental disclosure as a factor of sustainable development of the Russian business. In The International Scientific and Practical Forum Industry. Science. Competence. Integration. pp. 628-635. Springer.

Tripathi, M., Kashiramka, S., \& Jain, P. (2018). Flexibility in measuring corporate financial performance, EVA versus conventional earnings measures: Evidences from India and China. Global Journal of Flexible Systems Management, 19(2), 123-138.

Turner, R. K., Van Den Bergh, J. C., Söderqvist, T., Barendregt, A., Van Der Straaten, J., Maltby, E., et al. (2000). Ecological-economic analysis of wetlands: Scientific integration for management and policy. Ecological Economics, 35(1), 7-23.

Tzouvanas, P., Kizys, R., Chatziantoniou, I., \& Sagitova, R. (2020). Environmental disclosure and idiosyncratic risk in the European manufacturing sector. Energy Economics, 87, 104715.

Vogt, M., Hein, N., Rosa, F. S., \& Degenhart, L. (2017). Relationship between determinant factors of disclosure of information on environmental impacts of Brazilian companies. Estudios Gerenciales, 33(142), 24-38. https://doi.org/10.1016/j.estger.2016.10.007.

Wang, L., Xue, X., Shi, Y., Wang, Z., \& Ji, A. (2018). A dynamic analysis to evaluate the environmental performance of cities in China. Sustainability, 10(3), 862.

Wang, Y., Delgado, M. S., Khanna, N., \& Bogan, V. L. (2019). Good news for environmental self-regulation? finding the right link. Journal of Environmental Economics and management, 94, 217-235. https ://doi.org/10.1016/j.jeem.2019.01.009.

Welbeck, E. E., Owusu, G. M. Y., Bekoe, R. A., \& Kusi, J. A. (2017). Determinants of environmental disclosures of listed firms in Ghana. International journal of corporate social responsibility, 2(1), 11.

Wijsman, J., Troost, K., Fang, J., \& Roncarati, A. (2019). Global production of marine bivalves. Trends and challenges. Goods and services of marine bivalves (pp. 7-26). Cham: Springer.

Yao, S., \& Liang, H. (2019). Analyst following, environmental disclosure and cost of equity: Research based on industry classification. Sustainability, 11(2), 300.

Zeng, S., Xu, X., Dong, Z., \& Tam, V. W. (2010). Towards corporate environmental information disclosure: An empirical study in China. Journal of Cleaner Production, 18(12), 1142-1148.

Zhang, T., \& Xie, L. (2020). The protected polluters: Empirical evidence from the national environmental information disclosure program in China. Journal of cleaner production, 258, 120343.

Publisher's Note Springer Nature remains neutral with regard to jurisdictional claims in published maps and institutional affiliations.

\section{Affiliations}

\section{Andrew Osei Agyemang ${ }^{1}$ (D) Kong Yusheng ${ }^{1} \cdot$ Angelina Kissiwaa Twum $^{1}$ • Emmanuel Caesar Ayamba ${ }^{1} \cdot$ Maxwell Kongkuah $^{1} \cdot$ Mohammed Musah $^{1}$}

Kong Yusheng

yshkong@ujs.edu.cn

Angelina Kissiwaa Twum

5102191206@stmail.ujs.edu.cn 
Emmanuel Caesar Ayamba

eaayamba@bpoly.edu.gh

Maxwell Kongkuah

MaxwellKongkuah@outlook.com

Mohammed Musah

prophe2013@yahoo.com

1 School of Finance \& Economics, Jiangsu University, 301 Xuefu Road, Zhenjiang City 212013, People's Republic of China 